\title{
Physiological adaptations of Cyprideis torosa (Crustacea, Ostracoda) to hydrogen sulphide
}

\author{
Andreas Jahn ${ }^{1, *}$, Inez Gamenick ${ }^{2}$, Hans Theede ${ }^{1}$ \\ ${ }^{1}$ Institut für Meereskunde an der Universität Kiel, Abteilung Meereszoologie, Düsternbrooker Weg 20. \\ D-24105 Kiel, Germany \\ ${ }^{2}$ Zoologisches Institut und Zoologisches Museum, Universität Hamburg, Martin-Luther-King-Platz 3 , \\ D-20146 Hamburg, Germany
}

\begin{abstract}
The ostracod Cyprideis torosa, Jones 1850 is one of the most abundant species of benthic fauna in the shallow water areas of the Baltic Sea, even in sulphidic habitats. Investigations of the physiological basis of the high resistance to hypoxia and hydrogen sulphide show that the ostracod is indeed able to oxidize penetrating sulphide to non-toxic thiosulphate and sulphite and to eliminate the oxidation products rather quickly. This detoxification, however, is not effective enough to prevent an increase of sulphide in the ostracod's body. In spite of valve closure and consequently a low apparent diffusion coefficient of about $8 \times 10^{-7} \mathrm{~cm}^{2} \mathrm{~s}^{-1}$, sulphide concentration in the tissues increases rapidly. Ambient sulphide concentration (1 mM sulphide) was reached within $2 \mathrm{~h}$, due to the small size of the ostracod. High succinate values in the tissues during sulphide exposure indicate that $C$. torosa is able to switch over to anaerobiosis, even under oxic conditions ( $70 \%$ air saturation). Obviously. C. torosa can resist long-term sulphidic conditions due to its high capacity for long-term anaerobiosis.
\end{abstract}

KEY WORDS: Cyprideis torosa Hydrogen sulphide Diffusion. Anaerobiosis

\section{INTRODUCTION}

Hydrogen sulphide is known to be highly toxic to eukaryotic organisms because it inhibits cytochrome $c$ oxidase, the last step of the respiratory chain (National Research Council 1979, Bagarinao 1992). Hydrogen sulphide is considered to be an important ecological factor for marine benthic organisms (Vismann 1991b, Giere 1992, Grieshaber et al. 1992). Animals living in sulphidic habitats have developed strategies to cope with hypoxia and sulphide, e.g. a high capacity for long-term anaerobiosis (Theede et al. 1969. Theede 1973) and well-developed mechanisms for sulphide detoxification (for reviews see Somero et al. 1989, Vismann 1991b, Bagarinao 1992).

The ostracod Cyprideis torosa Jones, 1850 is one of the most abundant species of benthic fauna in the shallow coastal habitats of the Baltic Sea (Hermann \& Heip

•E-mail:ajahn@ifm.uni-kiel.d400.de
1982). Here, hydrogen sulphide in the sediment is detectable in considerable concentrations throughout the year (up to $5 \mathrm{mM}$ sulphide, J. Rethmeier pers. comm.). In field experiments, where hypoxia and high sulphide concentrations were induced artificially, the ostracod was the most tolerant species of the community (I. Gamenick unpubl. data). In the laboratory, $C$. torosa was found to be highly resistant to hydrogen sulphide in tolerance experiments: $50 \%$ of the ostracods survived at $1 \mathrm{mM}$ as well as at $1.8 \mathrm{mM}$ sulphide for 3 wk (Gamenick et al. in press).

The body length of adult Cyprideis torosa is only about $1 \mathrm{~mm}$, therefore they are considered by some authors to be meiofauna (Hermann et al. 1983). Due to the small size of the organism, it can be expected that hydrogen sulphide will penetrate rapidly into the tissues (Powell 1989). In this study the significance of sulphide diffusion and possible consequences for the efficiency of detoxification mechanisms were examined by exposing $C$. torosa to various hypoxic-sulphidic and 
oxic-sulphidic conditions for different periods of time. In this context, the ecological role of anaerobic metabolism as a physiological adaptation to hydrogen sulphide for C. torosa will be discussed.

\section{MATERIAL AND METHODS}

Animals. Live specimens of Cyprideis torosa were collected from the shallow eulittoral of Wismar Bay, Germany (Southern Baltic Sea), by the sieving of sediment through a $250 \mu \mathrm{m}$ sieve. The ostracods were kept in aquaria with natural sediment and aerated seawater $\left(14 \% \mathrm{~S}, 16^{\circ} \mathrm{C}\right)$ until used for the experiments.

Expt 1: Incubation at hypoxia combined with $1 \mathrm{mM}$ sulphide. For each experimental run, 100 specimens of Cyprideis torosa (about $30 \mathrm{mg}$ fresh mass) were inserted into a $60 \mathrm{ml}$ jar containing incubation medium. In order to prepare the incubation medium, a sulphide stock solution $(100 \mathrm{mM}, \mathrm{pH} 7.9)$ was made from $\mathrm{Na}_{2} \mathrm{~S} \cdot 9 \mathrm{H}_{2} \mathrm{O}$ crystals in artificial seawater $(14 \% \mathrm{~S})$. The stock solution was added to artificial oxygen-deficient seawater $(14 \%$ S, bubbled with pure nitrogen, buffered with $10 \mathrm{mM}$ HEPES, $\mathrm{pH}$ 7.9) to a final concentration of about $1 \mathrm{mM}$ sulphide $(990 \pm 75 \mu \mathrm{M}, \mathrm{pH}$ $7.84 \pm 0.14$ ). During the experiments sulphide concentrations decreased by not more than $10 \%$ of the initial value. The oxygen concentration in the incubation fluid was always below the detection limit of the oxygen electrode $\left(1 \mu \mathrm{M}_{2}\right)$. To prevent aeration, the sealed jars were placed in a 1 l container filled with hypoxic seawater with continuous nitrogen inflow and kept at $16^{\circ} \mathrm{C}$ for different periods of time: $1,2,6,12$, and $24 \mathrm{~h}(1 \mathrm{~d})$ and 2,3 , and $7 \mathrm{~d}$. For each time period 3 to 9 replicates were processed.

Expt 2: Incubation at oxia combined with $1 \mathrm{mM}$ sulphide. Oxic incubations (air saturation of $70.2 \pm 2.6 \%=$ $\left.198 \pm 7 \mu \mathrm{M} \mathrm{O}_{2}\right)$ for $24 \mathrm{~h}$ with $1 \mathrm{mM}$ sulphide $(1046 \pm$ $131 \mu \mathrm{M}, \mathrm{pH} 7.88 \pm 0.03$ ) were conducted in a flowthrough system in a constant temperature bath at $16^{\circ} \mathrm{C}$. The incubation medium was taken from two 11 bottles, one containing aerated seawater $(\mathrm{pH} 7.8$, buffered as described above) and the other a $100 \mathrm{mM}$ sulphide stock solution ( $\mathrm{pH} 7,9$, prepared as described above and kept hypoxic with overlying nitrogen). From these bottles, the solutions were simultaneously pumped through a mixing chamber and then a chamber $(1 \mathrm{ml})$ containing Cyprideis torosa, resulting in a total flow rate of $83 \mathrm{ml} \mathrm{h}^{-1}$, also passing a sulphideinsensitive polarographic oxygen sensor (connected to a recorder) and a $\mathrm{pH}$ electrode, both monitoring continuously. For sulphide measurements, $100 \mu$ l medium was sampled from the system every 3 to $6 \mathrm{~h}$. The experiments were conducted 3 times with $100 \mathrm{C}$. torosa each for 1,6 , and $24 \mathrm{~h}$.
Expt 3: Recovery. In order to study recovery from sulphidic conditions Cyprideis torosa were preincubated under hypoxia $\left(\mathrm{O}_{2}<1 \mu \mathrm{M}\right)$ and $1 \mathrm{mM}$ sulphide for $1 \mathrm{~d}$ as described above (Expt 1). Subsequently, the medium was replaced by previously aerated artificial seawater without sulphide, and the C. torosa were exposed to this medium for 1, 2, 6, 24, and $36 \mathrm{~h}$. Each experimental run was repeated twice with $100 \mathrm{C}$. torosa.

Expt 4: Influence of bacteria. Dense colonies of bacteria occurred inside the valves of the ostracods. In order to study the possible thiosulphate production of these bacteria, incubations with antibiotics were conducted. Cyprideis torosa were preincubated in normoxic seawater with chloramphenicol, gentamycin, and streptomycin (each $10 \mathrm{mg} \mathrm{m}^{-1}$ ) for $24 \mathrm{~h}$. After this treatment electron microscopy photographs showed lysed bacteria (R. Windoffer pers. comm.). Then the ostracods were exposed to hypoxia and $1 \mathrm{mM}$ sulphide $(920 \pm 100 \mu \mathrm{M}$, as described for Expt 1) with antibiotics for $1,2,6,12,24 \mathrm{~h}$ and for $3 \mathrm{~d}$ with 3 to 6 replicates $(100$ C. torosa each).

Expt 5: Anaerobic metabolism. In order to study anaerobic metabolism, Cyprideis torosa were exposed for $24 \mathrm{~h}$ to the following conditions: normoxia $(283 \mu \mathrm{M}$ $\left.\mathrm{O}_{2}\right)$, hypoxia $\left(\mathrm{O}_{2}<1 \mu \mathrm{M}\right)$, 70\% air saturation $(198 \pm$ $7 \mu \mathrm{M} \mathrm{O}_{2}$ ), using a gas mixing pump, and $70 \%$ air saturation with $1 \mathrm{mM}$ sulphide $(1076 \pm 110 \mu \mathrm{M})$, using the flow-through system as described for Expt 2. Each incubation was repeated 3 times with $300 \mathrm{C}$. torosa (about $90 \mathrm{mg}$ fresh mass).

$\mathrm{pH}$, oxygen and sulphide concentrations. At the beginning and end of each hypoxic incubation, $\mathrm{pH}$ was measured using a pH electrode (Ingold). Oxygen was determined with a polarographic, sulphide insensitive oxygen sensor (Orbisphere). The detection limit of the oxygen electrode was $1 \mu \mathrm{MO}_{2}(0.3 \%$ air saturation). In this study the terms 'normoxic', 'oxic', and 'hypoxic' correspond to $100 \%\left(283 \mu \mathrm{M} \mathrm{O}_{2}\right), 70 \%\left(198 \mu \mathrm{M} \mathrm{O} \mathrm{O}_{2}\right)$. and $<0.3 \%$ air saturation $\left(\mathrm{O}_{2}<1 \mu \mathrm{M}\right)$, respectively. In the flow-through system, $\mathrm{pH}$ and oxygen were monitored continuously. Sulphide concentrations of the medium were measured photometrically using the methylene blue method (Gilboa-Garber 1971) modified by Howarth et al. (1983), Sulphide occurs in different ionic forms, depending on the $\mathrm{pH}$ of the medium. This study refers to 'sulphide' as the sum of $\mathrm{S}^{2-}, \mathrm{HS}^{-}$, and undissociated $\mathrm{H}_{2} \mathrm{~S}$ unless mentioned explicitly.

Sulphide, thiosulphate and sulphite concentrations in tissues. The concentrations of sulphide and its oxidation products in the tissues of Cyprideis torosa were analysed by high-performance liquid chromatography (HPLC) using a modified method according to Newton et al. (1981) and Vetter et al. (1989). The samples (100 C. torosal were rinsed with oxygen-deficient seawater, dried with filter paper, weighed, and homogenized in a 
glass homogenizer ( $2 \mathrm{ml})$ with $20 \mu \mathrm{l}$ monobromobimane $(30 \mathrm{mM})$ and $200 \mu \mathrm{l}$ HEPES (200 mM, pH 8.0) After incubation for $10 \mathrm{~min}$ at room temperature in darkness, tissues and valves were separated by short centrifugation $(\sim 10000 \times g)$. Incubation of $110 \mu$ l of the supernatant with $100 \mu$ acetonitrile was performed at $56^{\circ} \mathrm{C}$ (10 min) for protein precipitation. Derivates were stabilized by adding $290 \mu \mathrm{l}$ methane sulphonic acid (25 mM). Before analysis, samples were centrifuged again, and $20 \mu \mathrm{l}$ of the supernatant was separated by Kontron-HPLC equipment (Data System 450-MT, Kontron Instruments, Munich, Germany) using an acetic

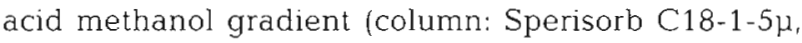
Latek, Eppelheim, Germany). Fluorescence detection of derivates was measured at $380 \mathrm{~nm}$ excitation and $480 \mathrm{~nm}$ emission wavelength. Standards were prepared accordingly. The concentration of the sulphide standard was checked by iodometrical titration (American Public Health Association 1976, Jander \& Jahr 1986). Concentration of thiosulphate and sulphite standards were determined gravimetrically.

Succinate. The succinate concentration in the tissues of Cyprideis torosa was taken as an indicator of anaerobic metabolism. Immediately after exposure, each sample $(300 \mathrm{C}$. torosa) was frozen in liquid nitrogen. The frozen specimens were homogenized on ice in $10 \mathrm{vol}-$ umes $(\mathrm{m} / \mathrm{V})$ of $0.33 \mathrm{M}$ perchloric acid with a glass homogenizer. After centrifugation (10 min at $\sim 10000 \times$ g), the supernatant was neutralized with $5 \mathrm{M} \mathrm{KOH}$ and $3 \mathrm{M} \mathrm{KHCO}_{3}$ and centrifuged again ( 2 min at $\sim 10000 \times g$ ). The concentration of succinate in the supernatant was determined enzymatically according to Beutler (1985) by measuring NADH consumption at $340 \mathrm{~nm}$ using pyruvate kinase/lactate dehydrogenase and succinyl-CoAsynthetase (Boehringer Mannheim, Germany).

Dry mass, valve mass, and water content. All data are given on a dry mass basis. For calculation of the dry mass, specimens of Cyprideis torosa were dried at $60^{\circ} \mathrm{C}$ for $1 \mathrm{~d}$ (dry mass including valves) followed by combustion at $550^{\circ} \mathrm{C}$ for $2 \mathrm{~h}$ (ash mass including valves). Since ash mass is negligible in comparison to valve mass, ash mass including valves was equated to valve mass. Water content of the tissues was calculated from the ratio of dry mass without valves to fresh mass without valves. The preparations were carried out 1 time with 54 C. torosa and 3 times with 20 C. torosa.

Statistics. All data are given as means with standard deviation. Their significance was analysed using the nonparametric $U$-test of Mann \& Whitney with a significance level of 5\% (Clauß \& Ebner 1982).

Calculation of apparent diffusion coefficient. The sulphide influx data measured in this study were used as an estimation of the apparent diffusion coefficient for total sulphide by including the following assumptions. According to Fick's second law, the time rate of concentration changing along the diffusion distance $x$ is

$$
\frac{\partial c}{\partial t}=D \frac{\partial^{2} c}{\partial x^{2}}
$$

where $c$ is the concentration, $t$ the time, and $D$ the diffusion coefficient. For a sphere the time rate is given by (Berg 1993)

$$
\frac{\partial C}{\partial t}=D \frac{1}{r^{2}} \frac{\partial}{\partial r}\left(r^{2} \frac{\partial C}{\partial r}\right)
$$

where $I$ is the radius. It can be assumed that sulphide accumulation over time in the tissues follows Michaelis-Menten kinetics:

$$
c(t)=\frac{c_{0} t}{\tau+t}
$$

where $c_{0}$ is the outer concentration of sulphide and $\tau$ the time after which $c_{0} / 2$ is attained inside. Maximal diffusion takes place when $\mathrm{t} \ll \tau$ :

$$
\begin{aligned}
& c(t) \rightarrow \frac{C_{0}}{\tau} t \\
& \Rightarrow \frac{\partial c}{\partial t}=\frac{C_{0}}{\tau}
\end{aligned}
$$

Substituting Eq. (4) into Eq. (2) gives

$$
D \frac{1}{r^{2}} \frac{\partial}{\partial r}\left(r^{2} \frac{\partial C}{\partial r}\right)=\frac{C_{0}}{\tau}
$$

Substitution with

$$
u=r^{2} \frac{\partial c}{\partial r}
$$

and integration from 0 to $u(r)$ and from 0 to the effective radius $r_{\mathrm{e}}$ respectively leads to

$$
\begin{aligned}
& D \int_{0}^{u(r)} \mathrm{d} u=\frac{C_{0}}{\tau} \int_{0}^{I_{r}} r^{2} \mathrm{~d} r \\
& \Rightarrow D r^{2} \frac{\partial C}{\partial r}=\frac{c_{0}}{\tau} \frac{1}{3} r_{\mathrm{e}}^{3}
\end{aligned}
$$

Maximal diffusion occurs at the beginning when the inner concentration $C_{\mathrm{i}}=0$. Therefore

$$
\begin{gathered}
D \int_{c_{0}}^{c_{1}=0} \partial c=\frac{1}{3} \frac{c_{0}}{\tau} \int_{0}^{r_{11}} r^{-2} \partial r \\
\Rightarrow-D c_{0}=-\frac{1}{3} \frac{c_{0}}{\tau} r_{e}^{3} \frac{1}{r_{e}} \\
\Rightarrow D=\frac{r_{\mathrm{e}}^{2}}{3 \tau}
\end{gathered}
$$

The effective radius $r_{\mathrm{e}}$ can be calculated from the water content $w$, the fresh mass of the animal $m$, and the density of water $\rho$ : 


$$
r_{\mathrm{t}^{\prime}}=\sqrt[3]{\frac{3}{4} \frac{w m}{\rho \pi}}
$$

The half-saturation period $\tau$ was estimated by using the reciprocal form of Eq. (3) as linear curve fitting (Lineweaver-Burk-Plot):

$$
\frac{1}{c}=\frac{\tau}{c_{0}} \frac{1}{t}+\frac{1}{c_{0}}
$$

$1 / c$ was calculated from the sum of sulphide, thiosulphate, and sulphite concentrations after hypoxic incubation times, $t$, by consideration of stoichiometric ratios and control values.

\section{RESULTS}

\section{Expt 1: Incubation at hypoxia combined with $1 \mathrm{mM}$ sulphide}

Exposure to hypoxia with $1 \mathrm{mM}$ sulphide caused high sulphide concentrations in the tissues of Cyprideis
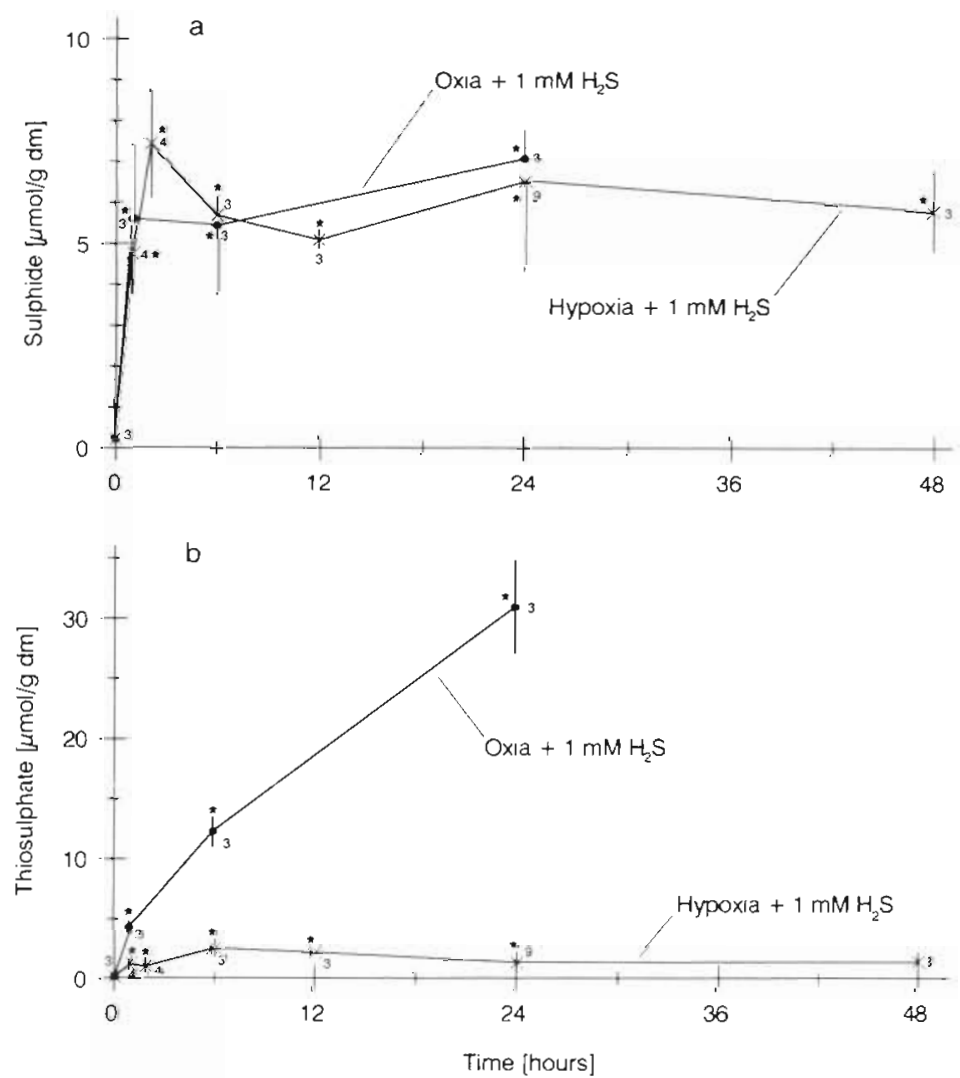

Fig. 1. Cyprideis torosa. Concentration of (a) sulphide and (b) thiosulphate in the tissues of ostracods after hypoxac $\left(\mathrm{O}_{2}<1 \mu \mathrm{M}\right)$ and oxic incubation $\left(198 \mu \mathrm{M} \mathrm{O}_{2}\right)$ with $1 \mathrm{mM}$ sulphide $\left(16^{\circ} \mathrm{C}, 14 \% \mathrm{~S}\right)$. Mean values in $\mu \mathrm{mol} \mathrm{g}^{-1}$ dry mass $\pm \mathrm{SD}$. Numbers indicate replicates with 100 C. torosa. "Significant difference to control ( $p \leq 0.05)$ torosa (Fig 1a). Within $1 \mathrm{~h}$, sulphide concentrations increased significantly from $0.22 \pm 0.07$ to $4.76 \pm$ $0.99 \mu \mathrm{mol} \mathrm{g}^{-1} \mathrm{dry}$ mass $(\mathrm{dm})$. The maximum value of $7.44 \pm 1.32 \mu \mathrm{mol} \mathrm{g}{ }^{-1} \mathrm{dm}$ was reached after $2 \mathrm{~h}$. After $7 \mathrm{~d}$ of exposure, the mean sulphide concentration in the tissues was $6.68 \pm 0.20 \mu \mathrm{mol} \mathrm{g}{ }^{-1} \mathrm{dm}$. Thiosulphate $\left(\mathrm{S}_{2} \mathrm{O}_{3}{ }^{2-}\right)$ reached a maximum concentration of $2.50 \pm 0.72 \mu \mathrm{mol}$ $\mathrm{g}^{-1} \mathrm{dm}$ after $6 \mathrm{~h}$ (Fig. $1 \mathrm{~b}$ ). During the following $7 \mathrm{~d}$ of incubation, the content decreased to $0.64 \pm 0.26 \mu \mathrm{mol} \mathrm{g}^{-1}$ $\mathrm{dm}$. As a further oxidation product, sulphite $\left(\mathrm{SO}_{3}{ }^{2-}\right)$ was detectable in low concentrations with a maximum of $0.56 \pm 0.19 \mu \mathrm{mol} \mathrm{g}^{-1} \mathrm{dm}$ after $6 \mathrm{~h}$.

\section{Expt 2: Incubation at oxia combined with $1 \mathrm{mM}$ sulphide}

Sulphide concentrations in the tissues increased quickly up to $5.60 \pm 1.82 \mu \mathrm{mol} \mathrm{g}{ }^{-1} \mathrm{dm}$ after $1 \mathrm{~h}$. An even higher value of $7.09 \pm 0.71 \mu \mathrm{mol} \mathrm{g} \mathrm{g}^{-1} \mathrm{dm}$ was reached after 24 h (Fig. 1a). However, there were no significant differences between oxic and hypoxic incubations. In contrast to sulphide, thiosulphate concentration of $30.92 \pm 3.90 \mu \mathrm{mol} \mathrm{g}{ }^{-1} \mathrm{dm}$ after $1 \mathrm{~d}$ of oxic incubation was significantly higher than in Expt 1 (Fig. 1b). Mean concentrations of sulphite were low, with a maximum value of $0.90 \pm 0.19 \mu \mathrm{mol} \mathrm{g}{ }^{-1} \mathrm{dm}$ after $1 \mathrm{~d}$ of incubation.

\section{Expt 3: Recovery}

After exposure to hypoxia with $1 \mathrm{mM}$ sulphide and subsequent change to normoxic seawater without sulphide, the concentration of sulphide in the tissues decreased during the first $2 \mathrm{~h}$ from $6.52 \pm 2.21$ to $3.25 \pm$ $0.48 \mu \mathrm{mol} \mathrm{g}{ }^{-1} \mathrm{dm}$ (Fig. 2). Thiosulphate content increased in the first hour from $1.31 \pm$ 0.84 up to $1.64 \pm 0.49 \mu \mathrm{mol} \mathrm{g}{ }^{-1} \mathrm{dm}$, then decreased within the next hour to $0.38 \pm$ $018 \mu \mathrm{mol} \mathrm{g}^{-1} \mathrm{dm}$ where it stabilized for the next $36 \mathrm{~h}$ (Fig. 2). The same pattern was found for sulphite.

\section{Expt 4: Influence of bacteria}

Treatment with antibiotics did not influence the concentrations of sulphide (Fig. 3a) and thiosulphate (Fig. 3b) in the tissues during hypoxic-sulphidic exposure. Thus, the contribution of bacteria inside the carapax during hypoxia is negligible. 


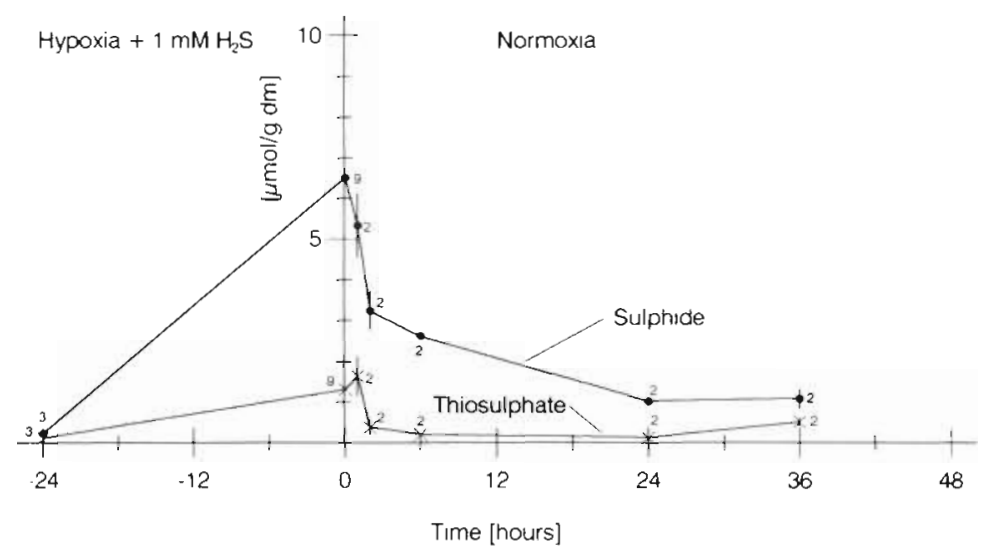

Fig. 2. Cyprideis torosa. Concentration of sulphide and thiosulphate in the tissues of ostracods after $1 \mathrm{~d}$ hypoxic-sulphidic incubation $(1 \mathrm{mM}$ sulphide) and subsequent exposure to normoxic seawater. For further details see Fig. 1

\section{Expt 5: Anaerobic metabolism}

After $1 \mathrm{~d}$ exposure to normoxia (100\% air saturation), low succinate concentrations of $16.3 \pm 0.6 \mu \mathrm{mol} \mathrm{g}^{-1} \mathrm{dm}$ were found in the tissues of Cyprideis torosa (Fig. 4). At reduced oxygen concentration of $70 \%$ air saturation, succinate values remained at the same level $\left(16.4 \pm 1.0 \mu \mathrm{mol} \mathrm{g}{ }^{-1} \mathrm{dm}\right)$. However, at hypoxia $1 \mathrm{O}_{2}<0.3 \%$ air saturation) succinate levels increased significantly up to $53.4 \pm 6.1 \mu \mathrm{mol}$ $\mathrm{g}^{-1} \mathrm{dm}$, indicating the onset of anaerobic pathways. In oxic conditions in the presence of sulphide $(70 \%$ air saturation, $1 \mathrm{mM}$ sulphide), succinate production increased significantly to $38.3 \pm 3.9 \mu \mathrm{mol} \mathrm{g}{ }^{-1} \mathrm{dm}$. This demonstrates that $C$. torosa switched to anaerobiosis under sulphidic conditions, even though oxygen was available. The lower succinate content in comparison to hypoxic condition shows that this change of metabolism was not complete.

\section{Dry mass, valve mass, and water content}

Valve mass contributed $37.8 \pm 5.2 \%(\mathrm{n}=4$ with 114 Cyprideis torosa in total) to the fresh mass of the ostracods. Dry mass without valves was $8.2 \pm 1.8 \%$ of the fresh mass including valves and $13.5 \pm 3.8 \%(n=4)$ of the fresh mass without valves, leading to a tissue water content of $86.5 \%$. Therefore, a maximum sulphide concentration of about 7 mol $\mathrm{g}^{-1} \mathrm{dm}$ (Fig. 1a) corresponded to $945 \mathrm{nmol}$ $\mathrm{g}^{-1}$ fresh mass without valves. Assuming a density of water of $1 \mathrm{~kg} \mathrm{l}^{-1}$ and a water content of $0.865,945 \mathrm{nmol} \mathrm{g}^{-1}$ fresh mass in the tissues equalled $1092 \mu \mathrm{mol}^{-1}$, which corresponded to the concentration of $1 \mathrm{mM}$ sulphide of the incubation medium. The fresh mass of 1 C. torosa without valve was 0.181 $\pm 0.052 \mathrm{mg}(\mathrm{n}=4$ with 114 C. torosa in total).

\section{Calculation of apparent diffusion coefficient}

Taking the water content $w=0.865$, the fresh mass of 1 Cyprideis torosa $m=$ $0.181 \mathrm{mg}$ and the density of water $\rho=1 \mathrm{~g}$ $\mathrm{cm}^{-3}$, Eq. (7), therefore, gives an effective radius $r_{\mathrm{e}}=0.033 \mathrm{~cm}$. Linear curve fitting of hypoxic incubations (Eq. 8) resulted in a half-saturation period of $\tau=0.125 \mathrm{~h}=450 \mathrm{~s}$. With these data an apparent diffusion coefficient of total sulphide $D=8.1 \times 10^{-7} \mathrm{~cm}^{2} \mathrm{~s}^{-1}$ for C. torosa was calculated (Eq. 6).
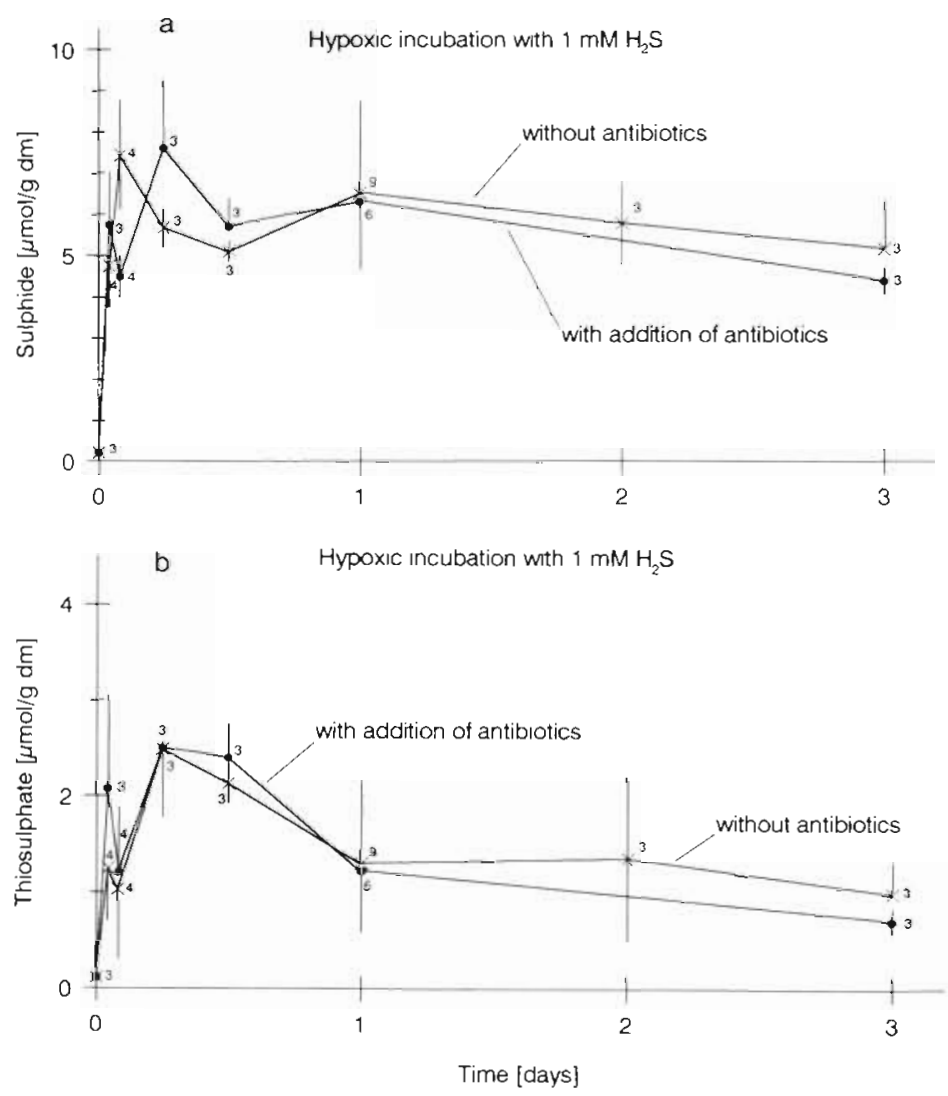

Fig. 3. Cyprideis torosa. Concentration of (a) sulphide and (b) thiosulphate in the tissues of ostracods after hypoxic-sulphidic incubation (1 mM sulphide) without and with antibiotics (chloramphenicol, gentamycin, streptomycin; each $10 \mathrm{mg} \mathrm{m}^{-1}$ ). For further details see Fig. 1 


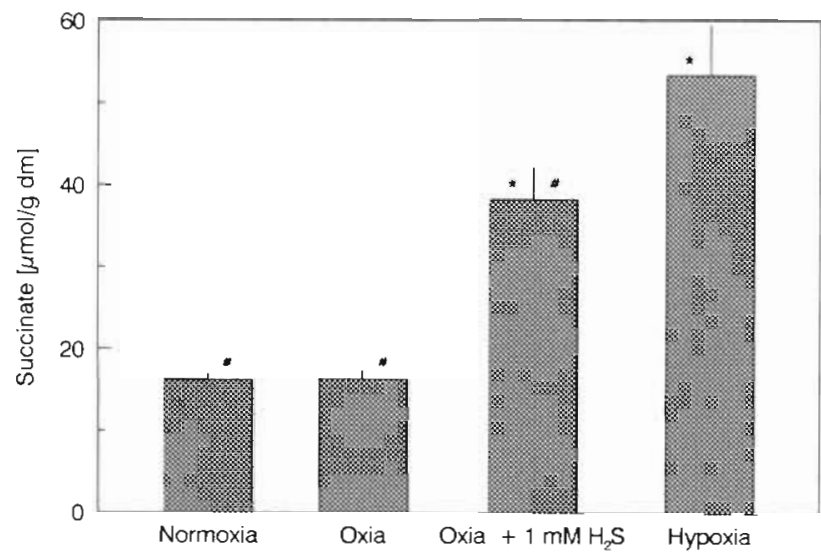

Fig. 4. Cyprideis torosa. Succinate concentration in the tissues of ostracods after $1 \mathrm{~d}$ of normoxic $\left(\begin{array}{ccc}283 & \mu \mathrm{M} & \mathrm{O}_{2}\end{array}\right)$, oxic (198 $\left.\mu \mathrm{M} \mathrm{O}_{2}\right)$, oxic-sulphidic (198 $\mu \mathrm{M} \mathrm{O}_{2}+1 \mathrm{mM}$ sulphide), and hypoxic $\left(\mathrm{O}_{2}<1 \mu \mathrm{M}\right)$ incubations $\left(16^{\circ} \mathrm{C}, 14 \% \mathrm{~S}\right)$. Mean values in $\mu \mathrm{mol} \mathrm{g}^{-1}$ dry mass $+\mathrm{SD}(\mathrm{n}=3$ with 300 C. torosa each). - Significant difference with respect to oxic incubation; "significant difference with respect to hypoxic incubation $(\mathrm{p} \leq 0.05)$

\section{DISCUSSION}

The ecologically important ostracod Cyprideis torosa is a widespread and dominant species in the sediment of shallow brackish water habitats (Hermann \& Heip 1982). Tolerance experiments showed that this species can withstand hypoxia combined with extremely high concentrations of $1 \mathrm{mM}$ and $1.8 \mathrm{mM}$ hydrogen sulphide for weeks (Gamenick et al. in press), whereas other crustaceans like Crangon crangon or Corophium volutator, which occur in the same habitat (Gamenick \& Giere 1995), are known to be very sensitive to hypoxia and sulphide. For the shrimp C. crangon, a mean lethal time ( $\mathrm{LT}_{50}$ ) of only $2 \mathrm{~h}$ was recorded in tolerance experiments under hypoxia as well as under hypoxia with $200 \mu \mathrm{M}$ sulphide (Theede et al. 1969). Hagerman \& Vismann (1995) demonstrated a high sensitivity to oxygen deficiency and hydrogen sulphide in C. crangon as well. For the amphipod $C$. volutator, a mean survival time of $4 \mathrm{~h}$ at hypoxia and of $2 \mathrm{~h}$ at hypoxia with $90 \mu \mathrm{M}$ sulphide was found (Gamenick et al, in press). In contrast to these species, the ostracod C. torosa is a pioneer organism which can colonize azoic, highly sulphidic sediment patches within $2 \mathrm{~d}$. Thus, it has to cope with hydrogen sulphide penetrating into its tissues.

Sulphide influx data from this study (Fig. 1a) were used for an estimation of the diffusion coefficient. This calculation takes into account not only sulphide diffusion through the body wall but also all diffusion barriers inside the whole organism. Therefore, it is an apparent diffusion coefficient summing up the diffusion through the valves and through soft membranes inside the tissues. Differences between internal and external $\mathrm{pH}$ are included in the calculation by using total sulphide data (sum of $\mathrm{S}^{2-}, \mathrm{HS}^{-}$and undissociated $\mathrm{H}_{2} \mathrm{~S}$, which is the primary diffusion species according to Powell 1989). Moreover, elimination of penetrated sulphide by oxidation to thiosulphate and sulphite is considered. Taking the ostracod's body as a sphere is appropriate because diffusion depends on surface area to volume ratio (Fick's first law) and a sphere is the geometrical body with the lowest area to volume ratio. Therefore, the calculation used in this study represents the most favourable case. However, for an exact determination of the half-saturation period, $\tau$, more shortterm sulphide exposure data are needed; therefore, only a rough estimation of the diffusion coefficient was possible.

In comparison to the diffusion coefficient for other species, the estimated coefficient of $8.1 \times 10^{-7} \mathrm{~cm}^{2} \mathrm{~s}^{-1}$ for Cyprideis torosa is very low. Julian \& Arp (1992) found a diffusion coefficient of $3.8 \times 10^{-6} \mathrm{~cm}^{2} \mathrm{~s}^{-1}$ for the body wall of the echiurid worm Urechis caupo (calculated from the sulphide permeability given by the authors and a diffusion distance of $0.2 \mathrm{~cm}$ ). Volkel \& Grieshaber (1992) gave a diffusion coefficient for undissociated $\mathrm{H}_{2} \mathrm{~S}$ of $4 \times 10^{-5} \mathrm{~cm}^{2} \mathrm{~s}^{-1}$ for the body wall of the peanut worm Sipunculus nudus. Powell (1989) assumed the diffusion coefficient of $\mathrm{H}_{2} \mathrm{~S}$ be equal to that of oxygen in water $\left(D_{\mathrm{H}_{2} \mathrm{~S}} \approx D_{\mathrm{O}_{2}} \approx 5 \times 10^{-6} \mathrm{~cm}^{2} \mathrm{~s}^{-1}\right)$. However, these data are difficult to compare because the authors only considered the diffusion through the body wall and Julian \& Arp (1992) referred to total sulphide, whereas Völkel \& Grieshaber (1992) and Powell (1989) regarded undissociated $\mathrm{H}_{2} \mathrm{~S}$. Due to its neutral charge, undissociated $\mathrm{H}_{2} \mathrm{~S}$ diffuses much easier than $\mathrm{HS}^{-}$leading to different diffusion coefficients. Nevertheless, it can be supposed that sulphide diffusion into the body of $C$. torosa is lower than into soft-bodied macrofauna species like $U$. caupo and $S$. nudus.

In spite of the high sulphide oxidation rate and the low sulphide diffusion coefficient, which is probably due to valve closure, Cyprideis torosa is not able to maintain a lower sulphide level inside when external sulphide contamination lasts longer than $2 \mathrm{~h}$. After this time, an equilibrium between sulphide concentrations inside and outside of the ostracod is attained. This is a consequence of the small size of the organism. Small organisms like $C$. torosa have a high surface area to volume ratio, leading to high diffusion of hydrogen sulphide into the tissues, even with a low diffusion coefficient. Eq. (6) shows that $\tau$ is proportional to $r_{e}{ }^{2} ;$ in other words, a small radius will lead to a very short time for attaining $c_{0} / 2$ at a given diffusion coefficient. Powell (1989) even postulated that meiofaunal species living in sulphidic habitats have a sulphide insensitivity because these organisms are so small that a sulphide 
detoxification system running at physiologically reasonable rates could never maintain internal sulphide concentration below toxic levels. The 'thiobios-concept', which provoked highly controversial discussions in the literature (Fenchel \& Riedl 1970, Boaden \& Platt 1971, Reise \& Ax 1979, 1980, Boaden 1980, Powell 1989, Giere 1992), moreover required sulphide as an ecological necessity for organisms living in the anoxic highly sulphidic deeper layers of the sediment. $C$. torosa lives on the sediment surface so that it stays in contact with the normoxic environment and only temporarily experiences high sulphide concentrations. Therefore, it cannot be considered as a 'thiobiotic' organism but can be classified according to Giere (1992) as a sulphide-tolerant, oxiphilic species.

If oxygen is available, Cyprideis torosa produces high concentrations of thiosulphate within short time periods (Fig. 1b). The oxidation of sulphide to thiosulphate (and to sulphite in lower quantities) is known for several macrofauna species as an important detoxification mechanism (Vismann 1991a, Jahn et al. 1992, Oeschger \& Vetter 1992, Völkel \& Grieshaber 1992, Windoffer \& Jahn 1995, Theede et al. 1996). In contrast to sulphite $\left(\mathrm{SO}_{3}{ }^{2-}\right)$, each thiosulphate molecule $\left(\mathrm{S}_{2} \mathrm{O}_{3}{ }^{2-}\right)$ represents the detoxification of 2 sulphide molecules. Therefore, thiosulphate is the favoured detoxification product, especially under low oxygen conditions (Somero et al. 1989, Vismann 1991 b). Sulphite is probably an intermediate oxidation product. O'Brien \& Vetter (1990) showed for the bivalve Solemya reidi that sulphide is first oxidized to sulphite. Then a second molecule of sulphide is added to form thiosulphate. However, the sulphide diffusion rate into the ostracod is higher than the oxidation rate to thiosulphate, indicating that these animals are not capable of detoxifying hydrogen sulphide as effectively as described for macrofaunal organisms. For some eukaryotic organisms, an exploitation of sulphide oxidation for energetic purposes has been described (Powell \& Somero 1986, Oeschger \& Vismann 1994, Völkel \& Grieshaber 1994, Oeschger \& Tschischka 1995, Tschischka \& Oeschger 1995). Maybe sulphide-driven ATP production, which is nevertheless only possible at low sulphide concentrations, is one reason for maintaining high sulphide oxidation rates. However, if sulphide contamination is too high, or lasts for too long a time, the aerobic metabolism of $C$. torosa will be blocked.

At hypoxia $\left(\mathrm{O}_{2}<1 \mu \mathrm{M}\right)$, the ostracods use anaerobic pathways, leading to an accumulation of succinate (Fig. 4), which is quite common during environmental anaerobiosis in marine invertebrates. However, for many crustaceans succinate is only a minor end product of anaerobiosis (Zebe 1982, Gäde 1983, Grieshaber et al. 1994, Hagerman \& Vismann 1995). The formation of lactate, as the typical end product of anaerobiosis for crustaceans, was not tested for Cyprideis torosa but the succinate accumulation shows that this pathway is at least important for the ostracods. Probably, this is an environmental adaptation because the formation of succinate instead of lactate yields more ATP per mole of glucose (Fields 1983, Grieshaber et al. 1994). Small decreases in environmental oxygen content do not exert a negative effect on C. torosa. The ostracods are able to maintain a fully aerobic metabolism at least down to $70 \%$ air saturation. Succinate production during oxic sulphide incubation demonstrates that $C$. torosa switches to anaerobiosis in spite of the presence of oxygen. Similar observations have been made for other marine invertebrates (Jahn et al. 1992, 1993, Oeschger \& Vetter 1992, Völkel \& Grieshaber 1992, 1994, Dubilier et al. 1994). Grieshaber et al. (1992) and Oeschger \& Vetter (1992) called this phenomenon 'sulphide-dependent anaerobiosis' and differentiated it from environmental anaerobiosis. However, even if an effect of hydrogen sulphide on other enzymes is known, its toxicity is mainly due to the inhibition of cytochrome $c$ oxidase and consequently the blocking of aerobic metabolism (Bagarinao 1992). Thus, hydrogen sulphide must also lead to anaerobiosis under oxic conditions and 'sulphide-dependent anaerobiosis' corresponds to environmental anaerobiosis.

In the field, high hydrogen sulphide concentrations often occur in combination with oxygen deficiency when aerobic metabolism is impossible. Consequently, the inhibition of cytochrome $c$ oxidase will have no effect on energy metabolism so that sulphide toxicity will be less significant to the organism. Species like Cyprideis torosa living in these variable habitats are able to use anaerobic pathways for long time periods. Thus, they can survive until the environmental conditions improve or they can escape. It is known that $C$. torosa maintains its mobility when exposed to sulphide (Gamenick et al. in press). The high capacity for longterm anaerobiosis with continued mobility is probably one of the most important prerequisites for survival in sulphidic habitats when the mitochondrial electron transport chain is blocked.

Since temporal and spatial fluctuations of hypoxic and sulphidic conditions are common in shallow water habitats, it is advantageous for Cyprideis torosa to be able to quickly respond to environmental change. The recovery experiments show a decline of internal sulphide concentration (Fig. 2), partly due to removal by diffusion and partly due to oxidation of internal sulphide to thiosulphate. The detoxification of residual sulphide in the tissues leads to an increase of thiosulphate content in the first hour, after which thiosulphate also declines. Obviously, the ostracods are able to oxidize sulphide effectively when oxygen conditions improve and then remove the oxidation products 
In this context, it seems to be of significance that dense colonies of bacteria occur inside the carapax of the ostracods. The density of these colonies depends on the sulphide concentration of the medium ( $R$. Windoffer pers. comm.), a situation comparable to that for ectosymbionts found on some nematodes and oligochaetes of sulphidic habitats (Ott et al. 1991, Giere 1992). Experiments with antibiotics, which killed or reduced the activity of the bacteria, showed no effect on the survival capacity of Cyprideis torosa (R. Windoffer pers. comm.) or sulphide oxidation during hypoxia (Fig. 3a). Therefore, these bacteria appear not to be ectosymbionts. Bacteria from the valves were cultured and showed the ability to oxidize thiosulphate to sulphate under normoxic conditions with high oxidation rates. During hypoxia the bacteria oxidize thiosulphate to elemental sulphur, tetrathionate, and other (not yet determined) sulphur compounds thereby reducing nitrate to nitrite. They are characterized by a slow growth rate and need large amounts of thiosulphate (A. Schneider pers. comm.). Due to the high competition of other thiosulphate-oxidizing bacteria with higher growth rates, it is suggested that these bacteria are commensals which have found a niche inside the carapax of $C$. torosa where they can directly use the thiosulphate produced by the ostracods as an energy source, comparable, e.g., to succinate utilization by sulphate-reducing bacteria on the shells of the clam Arctica islandica (Bussmann \& Reichardt 1991). Due to slower growth and lower thiosulphate oxidation rate at hypoxia and probably the lack of nitrate as electron acceptor (A. Schneider pers. comm.), no effect on thiosulphate concentration during hypoxia with or without bacteria could be found (Fig. 3b). When under normoxic conditions again, these bacteria may possibly help to eliminate thiosulphate by oxidizing it (Fig. 2).

In conclusion, Cyprideis torosa is indeed able to oxidize penetrating sulphide to thiosulphate, but due to the small size of the animal this detoxification is not effective enough. However, when oxygen conditions improve the ostracod is able to eliminate sulphide and its oxidation products rather quickly. The capacity for long-term anaerobiosis. which does not lead to immobility, enables the ostracod to survive or to escape unfavourable conditions. The high anaerobic capacity is the most important adaptation of $C$. torosa to living in unpredictable habitats of the shallow Southern Baltic Sea.

Acknowledgements. This work was funded by the German Bundesminister für Bildung, Wissenschaft, Forschung und Technologie (BMBF) as part of the joint research programme on sulphide and methane brotopes in the Baltic and North Sea ('DYSMON II': 03F0123D). We thank Dr Reinhard Windoffer for help with the flow-through system and for valuable dis- cussions. The physiological investigations on the bacteria were carried out by Andreas Schneider and Lilijana Podgorsek. We also acknowledge the helpful comments of 4 anonymous referees

\section{LITERATURE CITED}

American Public Health Association, American Water Works Association, Water Pollution Control Federation (1976) Standard methods for the examination of water and wastewater, 14 th edn, Washington. DC

Bagarinao T (1992) Sulfide as an environmental factor and toxicant: tolerance and adaptations in aquatic organisms. Aquat Toxicol 24:21-62

Berg HC (1993) Random walks in biology. Princeton University Press, Princeton

Beutler HO (1985) Succinate. In: Bergmeyer J, Graßl M (eds) Methods of enzymatic analysis. Vol VII. Verlag Chemie, Weinheim, p 25-33

Boaden PJS (1980) Meiofaunal thiobios and 'the Arenicola negation' case not proven. Mar Biol 58:25-29

Boaden PJS, Platt HM (1971) Daily migration patterns in an intertidal meiobenthic community. Thalassia Jugosl 7:1-12

Bussmann I, Reichardt W (1991) Sulfate-reducing bacteria in temporarily oxic sediments with bivalves. Mlar Ecol Prog Ser 78:97-102

Clauß G, Ebner H (1982) Statistik für Soziologen, Pädagogen, Psychologen und Mediziner, 4. Auflage. Bd 1 Grundlagen. Verlag Harri Deutsch, Thun

Dubilier N, Giere O, Grieshaber MK (1994) Concomitant effects of sulfide and hypoxia on the aerobic metabolism of the marine oligochaete Tubificoides benedii. J Exp Zool 269:287-297

Fenchel TM, Riedl RJ (1970) The sulfide system: a new community underneath the oxidized layer of marine sand bottoms. Mar Biol 7:255-268

Fields JHA (1983) Alternatives to lactic acid: possible advantages. J Exp Zool 228:445-457

Gäde G (1983) Energy metabolism of arthropods and mollusks during environmental and functional anaerobiosis. J Exp Zool 228:415-429

Gamenick I, Giere O (1995) Wiederbesiedlung ehemals anoxischer und hochsulfidischer Sedimente durch Makrozoobenthos. BODDEN 2:87-99

Gamenıck I, Jahn A, Vopel K. Giere O (in press) Hypoxıa and sulphide as structuring factors in a macrozoobenthic community at the shore of the Baltic Sea: colonisation studies and tolerance experiments. Mar Ecol Prog Ser

Giere $O(1992)$ Benthic life in sulfidic zones of the sea-ecological and structural adaptatıons to a toxic environment. Verh Dtsch Zool Ges 85(2):77-93

Gilboa-Garber N (1971) Direct spectrophotometric determination of inorganic sulfide in biological materials and in other complex mixtures. Anal Biochem 43:129-133

Grieshaber MK, Hardewig I, Kreutzer U, Pörtner HO (1994) Physiological and metabolic responses to hypoxia in invertebrates. Rev Physiol Biochem Pharmacol 125:43-147

Grieshaber MK, Hardewig I, Kreutzer U. Schneider A, Volkel $\mathrm{S}$ (1.992) Hypoxia and sulfide tolerance in some marine invertebrates. Verh Dtsch Zool Ges 85(2):55-76

Hagerman L, Vismann B (1995) Anaerobic metabolism in the shrimp Crangon crangon exposed to hypoxia, anoxia and hydrogen sulfide. Mar Biol 123:235-240

Herman PMJ, Heip C (1982) Growth and respiration of Cyprideis torosa Jones 1850 (Crustacea Ostracoda). Oecologia 54:300-303 
Herman PMJ, Heip C, Vranken G (1983) The production of Cyprideis torosa Jones 1850 (Crustacea, Ostracoda). Oecologia 58:326-331

Howarth RW, Giblin A, Gale J, Petersen BJ, Luther GW III (1983) Reduced sulfur compounds in the pore waters of a New England salt marsh. Eco! Bull 35:135-152

Jahn A, Oeschger R, Theede H (1992) Auswirkungen von Schwefelwasserstoff auf den Stoffwechsel ausgewählter Polvchaeten aus der Nord- und Ostsee. Verh Dtsch Zool Ge:s 85(1):22

Jahn A, Theede H, Oeschger R (1993) Unterschiedliche Fähıkeiten zur Schwefelwasserstoffentgiftung bei Populationen von Macoma balthica. Verh Dtsch Zool Ges 86(1):94

Jander G, Jahr KF (1986) Maßanalyse, 2. Auflage. Walter de Gruyter-Verlag, Berlin

Julian D. Arp AJ (1992) Sulfide permeability in the marine invertebrate Urechis caupo. J Comp Physiol B 162:59-67

National Research Council, Committee on Medical and Biologic Effects of Environmental Pollutants, Subcommittee on Hydrogen Sulfide (1979) Hydrogen sulfide. University Park Press, Baltimore

Newton GL, Dorian R, Fahey RC (1981) Analysis of biological thiols: derivatization with monobromobimane and separation by reverse-phase high-performance liquid chromatography. Anal Biochem 114:383-387

O'Brien J, Vetter RD (1990) Production of thiosulphate during sulphide oxidation by mitochondria of the symbiontcontaining bivalve Solemya reidi. J Exp Biol 149:133-148

Oeschger R, Tschischka K (1995). Bedeutung der mitochondrialen Sulfidoxidation bei nereiden Polychaeten. Verh Dtsch Zool Ges 88(1):69

Oeschger R, Vetter RD (1992) Sulfide detoxification and tolerance in Halicryptus spinulosus (Priapulida): a multiple strategy. Mar Ecol Prog Ser 86:167-179

Oeschger R, Vismann B (1994) Sulphide tolerance in Heteromastus filiformis (Polychaeta): mitochondrial adaptations. Ophelia 40(2):147-158

Ott J, Novak R, Schiemer F, Hentschel U, Nebelsick M, Polz $M$ (1991) Tackling the sulfide gradient: a novel strategy involving marine nematodes and chemoautotrophic ectosymbionts. PSZN I: Mar Ecol 12(3):261-279

Powell E (1989) Oxygen, sulfide and diffusion: why thiobiotic meiofauna must be sulfide-insensitive first-order respirers. J Mar Res 47:887-932

Powell MA, Somero GN (1986) Hydrogen sulfide oxidation is coupled to oxidative phosphorylation in mitochondria of Solemya reidi. Science 233:563-566

This article was submitted to the editor
Reise K, Ax P (1979) A meiofaunal 'thioblos' limited to the anaerobic sulfide system of marine sand does not exist. Mar Biol 54:225-237

Reise K, Ax P (1980) Statement on the thiobios-hypothesis. Mar Biol 58:31-32

Somero (iN, Chuldress JJ, Anderson AE (1989) Transport, metabolism, and detoxification of hydrogen sulfide in anımals from sulfide-rich marine environments. CRC Crit Rev Aquat Sci 1:591-614

Theede H (1973) Comparative studies on the influence of oxygen deficiency and hydrogen sulphide on marine bottom invertebrates. Neth J Sea Res 7:244-252

Theede H, Oeschger R, Jahn A. (1996) Reactions of sublittoral marıne invertebrates of the Baltic Sea to hydrogen sulphide and hypoxia. [n: Andrushaitis A (ed) Proceedings of 13th Baltic Marine Biologists Symposium, Riga 1993 (in press)

Theede H, Ponat A, Hiroki K, Schlieper C (1969) Studies on the resistance of marine bottom invertebrates to oxygendeficiency and hydrogen sulphide. Mar Biol 2:325-337

Tschischka K, Oeschger R (1995) Mitochondrial sulphide oxidation in selected marine invertebrates. Proceedings of 4th International Congress of Comparative Physiology and Biochemistry. Physiol Zool 68(4):1.35

Vetter RD, Matrai PA, Javor B, O'Brien J (1989) Reduced sulfur compounds in the manne environment. Analysis by high-performance liquid chromatography. In: Saltzman ES, Cooper WJ (eds) Biogenic sulfur in the environment. American Chemical Society Symposiums Series No. 393, p 243-261

Vismann B (1991a) Physiology of sulfide detoxification in the ısopod Saduria (Mesidoted) entomon. Mar Ecol Prog Ser $76: 283-293$

Vismann B (1991b) Sulfide tolerance: physiological mechanısms and ecological implications. Opheha 34:1-27

Volkel S, Grieshaber MK (1992) Mechanisms of sulphide tolerance in the peanut worm, Sipunculus nudus (Sipunculidae) and in the lugworm, Arenicola marina (Polychaeta). J Comp Physiol B 162:469-477

Völkel S, Grieshaber MK (1994) Oxygen dependent sulfide detoxification in the lugworm Arenicola marna. Mar Biol 118:137-147

Windoffer R, Jahn A (1995) Untersuchungen zur Sulfidtoleranz von Macoma balthica. BODDEN 2:235-238

Zebe E (1982) Anaerobic metabolism in Upogebia pugettensis and Callianassa californiensis (Crustacea. Thalassinidea) Comp Biochem Physiol 72B(4):613-617

Manuscript first received: March 14, 1996

Revised version accepted: July 25, 1996 